\title{
KEMAMPUAN SISWA DALAM PEMECAHAN MASALAH GEOMETRI BERDASARKAN TINGKAT BERPIKIR VAN HIELE
}

\section{STUDENTS' COMPTENCE IN SOLVING GEOMETRIC PROBLEM BASED ON VAN HIELE'S MODEL}

\author{
Huratul Ain*, Baidowi dan Hapipi \\ Program Studi Pendidikan Matematika FKIP Universitas Mataram, Mataram, Indonesia \\ Email: huratul.smantipc@gmail.com, baidowiunram@gmail.com, hapipiunram@gmail.com
}

Diterima: 14 Mei 2020. Disetujui: 15 Mei 2020. Dipublikasikan: 12 Juni 2020

\begin{abstract}
Abstrak: Tujuan penelitian ini adalah untuk mendeskripsikan kemampuan pemecahan masalah geometri peserta didik kelas VIII MTs Negeri 1 Mataram tahun pelajaran 2018/2019 berdasarkan tingkat berpikir Van Hiele. Metode yang digunakan dalam penelitian ini yaitu tes dan wawancara. Hasil penelitian menunjukan bahwa tingkat berpikir peserta didik kelas VIII MTs Negeri 1 Mataram secara umum dominan berada pada level 0 (visualisasi) yaitu sebanyak 47 orang $(48,45 \%)$ dari 97 peserta didik yang mengikuti tes. Dalam pemecahan masalah geometri sesuai tahapan Polya, peserta didik yang berada pada kelompok level 0 (visualisasi) sudah mampu melakukan tahap memahami masalah dengan baik namun masih kurang sempurna dalam membuat rencana dan melaksanakan rencana penyelesaian. Peserta didik kelompok level 1 (analisis) sudah mampu melakukan tahap memahami masalah, membuat rencana dan melaksanakan rencana, namun dalam tahap melihat kembali, peserta didik tidak mampu memeriksa kembali hasil penyelesaiannya. Peserta didik kelompok level 2 (deduksi informal) sudah mampu melakukan tahap memahami masalah, membuat rencana, melaksanakan rencana penyelesaian dan melihat kembali meskipun belum sempurna pada tahap melihat kembali. Peserta didik kelompok level 3 (deduksi) memiliki kemampuan pemecahan masalah yang sangat baik, mereka sudah mampu melakukan tahap memahami masalah, membuat rencana, melaksanakan rencana dan melihat kembali dengan tepat dan proses perhitungan juga dilakukan dengan tepat. Hal tersebut menunjukan bahwa semakin tinggi tingkat berpikir Van Hiele peserta didik, maka kemampuan pemecahan masalah geometri yang dimilikinya akan semakin baik.
\end{abstract}

Kata Kunci: Geometri, Pemecahan Masalah, Tingkat Berpikir, Van Hiele

\begin{abstract}
The purpose of this research was to describe the ability of problem solving on geometry of $8^{\text {th }}$ grade students at MTsN 1 Mataram based on Van Hiele thinking level on year academic 2018/2019. The research metodology used was test and interview. The results showed that the level of thinking of $8^{\text {th }}$ grade students at MTsN 1 Mataram was generally dominant at level 0 (visualization phase), that is 47 students (48.45\%) from 97 students who took the test. To solve geometry problems according to Polya's stages, students at level 0 (visualization phase) have been able to understand the problem well, but still imperfect in devise and carry out the plans to solve the problem. Students at level 1 (analysis phase) have been able to understand the problem, devise and carry out the plans, but in the stage of looking back, students were not able to check the results of their completion. Students at level 2 (informal deduction phase) have been able to understand the problem, devise and carry out the plans and looking back even though it was not perfect at the stage of looking back. Students at level 3 (deduction phese) have excellent problem solving skills, they have been able to understand the problem, devise and carry out the plans and looking back properly and also the calculation process was carried out correctly. This showed that the students at the higher level of Van Hiele thinking have better ability to solve geometry problems.
\end{abstract}

Keyword: Geometry, Problem Solving, Thinking Level, Van Hiele

\section{PENDAHULUAN}

Geometri adalah salah satu cabang matematika yang mempelajari tentang titik, garis, bidang dan benda ruang beserta sifat- sifatnya, ukuran-ukurannya, dan hubungannya antara yang satu dengan yang lain [1]. Pada dasarnya geometri mempunyai peluang yang sangat besar untuk dipahami oleh peserta didik [2]. Hal ini karena ide-ide geometri sudah dikenal oleh peserta didik sejak sebelum masuk sekolah, seperti pengenalan garis, bidang dan ruang.

Salah satu tujuan dari pembelajaran geometri adalah agar peserta didik dapat menjadi pemecah masalah yang baik [3]. Pemecahan masalah merupakan pilar penting dalam mempelajari matematika. Pemecahan masalah adalah "jantung" dari matematika (heart of mathematics) [4]. Alasan perlunya pemecahan masalah yaitu memberi kelancaran bagi peserta didik dalam membangun suatu konsep dan berpikir matematis serta untuk memiliki pemahaman masalah yang kuat [5].

Polya [6] menjelaskan bahwa pemecahan masalah adalah menemukan makna yang dicari sampai akhirnya dapat dipahami dengan jelas. Memecahkan masalah bermakna menjawab suatu pertanyaan dimana metode untuk mencari solusi dari pertanyaan tersebut tidak dikenal terlebih dahulu [4]. 
Untuk menemukan suatu solusi, peserta didik harus menggunakan hal-hal yang telah dipelajari sebelumnya dan melalui proses dimana mereka akan mengembangkan pemahaman-pemahaman matematika baru.

Dalam proses pemecahan masalah, tentunya terdapat tahapan-tahapan yang harus dilalui. Tahapan pemecahan masalah yaitu; memahami masalah (understanding the problem), membuat rencana pemecahan (devising a plan), melaksanakan rencana (carrying out the plan) dan melihat kembali (looking back) [7].

Faktanya, kemampuan pemecahan masalah peserta didik di Indonesia masih rendah. Dari hasil survey TIMSS (Trends in Mathematics and Science Study) yang diselenggarakan oleh International Association for the Evaluation of Educational Achievement (IEA) pada tahun 2011 menempatkan Indonesia pada peringkat 52 dari 59 negara yang turut berpartisipasi dengan perolehan rerata skor peserta didik yaitu 386. Secara rinci dituliskan skor peserta didik Indonesia yaitu 386 untuk pengetahuan (knowing), 384 untuk penerapan (applying), dan 388 untuk penalaran (reasoning), sedangkan rerata skor internasional adalah 500 [8]. Skor yang diperoleh tersebut berada signifikan di bawah rerata skor internasional. Ini berarti pengetahuan (knowing), penerapan (applying), dan penalaran (reasoning) peserta didik Indonesia masih berada di bawah standar. Sementara itu, penalaran (reasoning) dan pemecahan masalah sangatlah berkaitan. Menurut Dunbar\& Fugelsang [9] reasoning atau penalaran dapat menjadi bagian dari pemecahan masalah. Misalnya, ketika memecahkan suatu masalah baru, seseorang sering berpikir mengenai solusinya dengan dikaitkan pada masalah yang serupa. Proses mengaitkan dengan masalah serupa ini disebut sebagai penalaran. Dengan demikian, dari hasil TIMSS dapat dikatakan bahwa kemampuan pemecahan masalah matematika peserta didik Indonesia masih rendah.

Berdasarkan wawancara dengan guru mata pelajaran matematika di MTsN 1 Mataram, diketahui bahwa dalam setiap pembelajaran, masalah yang sering terjadi pada peserta didik adalah kesulitan peserta didik memahami pelajaran dan memecahkan masalah. Peserta didik mengalami kesulitan dalam hal pemecahan masalah karena kurangnya pemahaman konsep terhadap materi pembelajaran. Terkadang peserta didik tidak mampu mengikuti apa yang diajarkan oleh guru, karena tidak dipungkiri ada perbedaan proses berpikir antara peserta didik dan guru.

Dalam menyelesaikan soal geometri peserta didik perlu menganalisis permasalahan yang ada, kemudian menyesuaikannya dengan informasi yang pernah diberikan selama pembelajaran. Masingmasing peserta didik tentu akan berbeda dalam menyusun dan mengolah informasi yang mereka dapatkan sehingga tidak menutup kemungkinan setiap peserta didik memiliki kemampuan pemecahan masalah yang berbeda-beda. Perbedaan antar peserta didik dalam menyelesaikan masalah geometri dikarenakan perbedaan tingkat berpikirnya [2].

Kemampuan berpikir geometri Van Hiele adalah suatu kemampuan yang menggambarkan tentang kemajuan tingkat-tingkat berpikir peserta didik dalam belajar geometri, proses mentransformasikan informasi geometri dalam memori, untuk membentuk konsep, pemecahan masalah, bernalar, membuat kesimpulan, dan mampu menghubungkan ide-ide geometri [10]. Sehingga setiap tingkatan berpikir Van Hiele dapat mempengaruhi tingkat kemampuan pemecahan masalah peserta didik.

Berdasarkan teori Van Hiele peserta didik akan melalui lima tingkat berpikir dalam memahami geometri, yaitu: level 0 (Visualisasi), level 1 (Analisis), level 2 (Deduksi Informal), level 3 (Deduksi), dan level 4 (Ketepatan) [11]. Setiap tingkat berpikir Van Hiele menunjukkan karakteristik proses berpikir peserta didik dalam belajar geometri dan pemahamannya dalam konteks geometri. Setiap tingkat berpikir Van Hiele akan dilalui peserta didik secara berurutan [3]. Dengan demikian, peserta didik harus melewati suatu tingkat dengan matang sebelum menuju tingkat selanjutnya.

Seorang guru profesional sudah sewajarnya memperhatikan kecerdasan dan tingkat berpikir peserta didiknya. Seorang guru perlu mengetahui kemampuan pemecahan masalah dalam tiap tingkat berpikir peserta didik sebagai keunikan yang dimiliki oleh peserta didik tersebut dan sebagai dasar pemilihan metode pengajaran yang sesuai dengan kebutuhan peserta didik. Dengan adanya kecocokan antara metode mengajar yang sesuai dengan tingkat berpikir dan kemampuan pemecahan masalah peserta didik, maka kemampuan pemecahan masalah geometri dan hasil belajar peserta didik dapat ditingkatkan.

Berdasarkan uraian latar belakang di atas, maka yang menjadi pertanyaan penelitian dalam penelitian ini adalah "Bagaimana kemampuan pemecahan masalah geometri peserta didik kelas VIII MTs Negeri 1 Mataram tahun pelajaran 2018/2019 berdasarkan tingkat berpikir Van Hiele?"

\section{METODE PENELITIAN}

Penelitian ini bertujuan untuk mendeskripsikan kemampuan pemecahan masalah geometri peserta didik berdasarkan tingkat berpikir Van Hiele. Penelitian ini dilaksanakan di MTs Negeri 1 Mataram. Populasi dalam penelitian ini adalah seluruh peserta didik kelas VIII MTs Negeri 1 Mataram Tahun Pelajaran 2018/2019. Di MTs Negeri 1 Mataram, kelas VIII dikategorikan menjadi 2 jenis kelas yaitu kelas unggulan dan kelas reguler. Populasi pada penelitian ini berstrata sehingga teknik sampling yang digunakan dalam penelitian ini adalah teknik Proportionate Stratified Random Sampling. Teknik 
pengumpulan data yang digunakan yaitu; teknik tes dan wawancara. Data penelitian ini berupa hasil tes penggolongan tingkat berpikir Van Hiele dan tes kemampuan pemecahan masalah geometri peserta didik pada materi bangun ruang sisi datar. Data yang diperoleh selanjutnya dianalisis dan dideskripsikan. Pada tahap wawancara, dipilih 10 dari 97 peserta didik yang mewakili masing-masing tingkat berpikir Van Hiele dalam pemecahan masalah geometri khususnya pada materi bangun ruang sisi datar guna menggali informasi lebih mendalam dari proses dan hasil mereka dalam menyelesaikan soal.

\section{HASIL DAN PEMBAHASAN}

Pengelompokan peserta didik dalam tingkat perkembangan berpikir Van Hiele didasarkan pada kriteria pengelompokan level berpikir peserta didik sesuai analisis tes tingkat berpikir Van Hiele. Berdasarkan hasil tes diperoleh 8 peserta didik pada level Pre 0 (previsualisasi), 47 peserta didik pada level 0 (visualisasi), 30 peserta didik pada level 1 (analisis), 8 peserta didik pada level 2 (deduksi informal), 4 peserta didik pada level 3 (deduksi), dan tidak ada peserta didik yang mencapai level 4 (rigor/ketepatan). Sehingga, dapat diketahui bahwa mayoritas peserta didik kelas VIII MTs Negeri 1 Mataram berada pada level 0 (visulisasi), akan tetapi masih ada peserta didik yang belum mampu mencapai level 0 (visualisasi) sehingga peneliti mengkategorikan peserta didik tersebut ke dalam level Pre 0 (Previsualisasi). Persentase dari banyaknya peserta didik kelas VIII MTs Negeri 1 Mataram pada masing-masing tingkat berpikir Van Hiele disajikan pada tabel 1.

Tabel 1. Hasil Pengelompokan Tingkat Berpikir Peserta Didik Berdasarkan Tingkat Berpikir Van Hiele

\begin{tabular}{llcc}
\hline No & Tingkat Berpikir Peserta Didik & Banyak Peserta Didik & Persentase \\
\hline $\mathbf{1}$ & Pre 0 (Previsualisasi) & 8 & $8,25 \%$ \\
$\mathbf{2}$ & Level 0 (Visualisasi) & 47 & $48,45 \%$ \\
$\mathbf{3}$ & Level 1 (Analisis) & 30 & $30,93 \%$ \\
$\mathbf{4}$ & Level 2 (Deduksi Informal) & 8 & $8,25 \%$ \\
$\mathbf{5}$ & Level 3 (Deduksi) & 4 & $4,12 \%$ \\
$\mathbf{6}$ & Level 4(Rigor/Ketepatan) & 0 & $0 \%$ \\
& Jumlah & $\mathbf{9 7}$ & $\mathbf{1 0 0 \%}$ \\
\hline
\end{tabular}

Tabel 2. Persentase Tingkat Kemampuan Pemecahan Masalah Geometri Peserta Didik pada MasingMasing Level Berpikir Van Hiele menurut Polya

\begin{tabular}{|c|c|c|c|c|}
\hline No & Tingkat Berpikir Peserta Didik & $\begin{array}{c}\text { Kriteria Tingkat } \\
\text { Kemampuan Pemecahan } \\
\text { Masalah }\end{array}$ & $\begin{array}{c}\text { Banyak } \\
\text { Peserta Didik }\end{array}$ & $\begin{array}{c}\text { Persentase } \\
(\%)\end{array}$ \\
\hline \multirow[t]{2}{*}{1} & Pre 0 (Previsualisas) & Kurang Baik & 8 & 8,25 \\
\hline & Level 0 (Visualisasi) & Baik & 14 & 14,43 \\
\hline \multirow[t]{3}{*}{2} & & Cukup Baik & 27 & 27,83 \\
\hline & & Kurang Baik & 6 & 6,19 \\
\hline & Level 1 (Analisis) & Sangat Baik & 2 & 2,06 \\
\hline \multirow[t]{2}{*}{3} & & Baik & 22 & 22,68 \\
\hline & & Cukup Baik & 6 & 6,19 \\
\hline \multirow{2}{*}{4} & Level 2 (Deduksi Informal) & Sangat baik & 2 & 2,06 \\
\hline & & Baik & 6 & 6,19 \\
\hline 5 & Level 3 (Deduksi) & Sangat Baik & 4 & 4,12 \\
\hline 6 & Level 4 (Ketepatan) & - & - & - \\
\hline
\end{tabular}

Pada level 4 (Rigor/ketepatan), peserta didik kelas VIII MTs Negeri 1 Mataram belum mampu untuk mencapai level tersebut. Karena pada level 4 (Rigor/ketepatan) peserta didik harus mampu memahami betapa pentingnya ketepatan dari prinsipprinsip dasar yang melandasi suatu pembuktian. Peserta didik pada level 4 (rigor/ketepatan) sudah memahami betapa pentingnya ketepatan dari prinsipprinsip dasar yang melandasi suatu pembuktian karena merupakan level tertinggi dalam memahami geometri sehingga pada tahap ini memerlukan tahap berpikir yang kompleks dan rumit [12].
Dalam penelitian ini, deperoleh fakta bahwa pserta didik yang gagal mencapai tingkat sebelumnya, maka juga akan gagal mencapai tingkat selanjutnya. Semua anak mempelajari geometri dengan melalui tingkat-tingkat tersebut dengan urutan yang sama dan tidak dimungkinkan adanya tingkat yang diloncati [13].

Bedasarkan hasil penelitian dan analisis data yang mengacu pada pemecahan masalah menurut polya, dapat diketahui bahwa peserta didik pada level Pre 0 (previsualisasi) rata-rata memiliki kemampuan pemecahan masalah geometri yang kurang baik. 
Peserta didik pada level 0 (visualisasi) rata-rata memiliki kemampuan pemecahan masalah geometri yang cukup baik. Peserta didik pada level 1 (analisis) dan level 2 (deduksi informal) rata-rata memiliki kemampuan pemecahan masalah geometri yang baik. Sedangkan, Peserta didik pada level 3 (deduksi) ratarata memiliki kemampuan pemecahan masalah geometri yang sangat baik. Adapun persentase tingkat kemampuan pemecahan masalah peserta didik kelas VIII MTs Negeri 1 Mataram menurut Polya pada tiap level berpikir Van Hiele disajikan dalam tabel 2.

Adapun deskripsi kemampuan pemecahan masalah geometri peserta didik kelas VIII MTs Negeri 1 Mataram berdasarkan tingkat berpikir Van Hiele adalah sebagai berikut:

\section{Kemampuan yang Diperoleh Kelompok Level 0 (Visualisasi)}

Mayoritas peserta didik kelas VIII MTs Negeri

1 Mataram yang berada pada level 0 (visulisasi) memiliki kemampuan pemecahan masalah yang cukup baik. Peserta didik yang berada pada tahap level 0 (Visualisasi), rata-rata memiliki kemampuan yang baik dalam memahami masalah. Peserta didik pada level 0 yang kemampuan pemecahan masalahnya dikategorikan baik sudah mampu menuliskan dan menjelaskan apa yang diketahui dan ditanyakan dari soal dengan benar dan lengkap. Selanjutnya, dari peserta didik yang kemampuan pemecahan masalahnya cukup baik dan kurang baik, diperoleh bahwa peserta didik tersebut mampu menjelaskan apa yang diketahui dan apa yang ditanyakan dari soal dengan benar walaupun pada pekerjaannya, ia tidak lengkap menuliskan apa yang diketahui dan apa yang ditanyakan.

Peserta didik yang berada pada tahap level 0 (Visualisasi), rata-rata memiliki kemampuan yang cukup baik dalam membuat rencana. Peserta didik yang kemampuan pemecahan masalahnya dikategorikan baik dan cukup baik pada tahap ini sudah mampu merencanakan penyelesaian masalah dengan menuliskan dan menjelaskan aturan mtematika (rumus) dengan benar namun pada beberapa pekerjaannya masih kurang tepat dalam menuliskan rumus yang digunakan untuk menyelesaikan soal tersebut. Selanjutnya, untuk peserta didik yang kemampuan pemecahan masalahnya kurang baik, diperoleh bahwa peserta didik tersebut mampu merencanakan penyelesaian masalah dengan menuliskan aturan mtematika (rumus) pada beberapa soal namun kurang lengkap sedangkan beberapa soal lainnya peserta didik tidak mampu menuliskan aturan mtematika (rumus) yang digunakan karena beranggapan bahwa soal yang diberikan cukup sulit.

Peserta didik yang berada pada tahap level 0 (Visualisasi), rata-rata memiliki kemampuan yang cukup baik dalam melaksanakan rencana penyelesaian. Peserta didik yang kemampuan pemecahan masalahnya baik dan cukup baik sudah mampu menjelaskan dan melaksanakan rencana yang telah ditentukan namun sering melakukan kesalahan ketika melakukan perhitungan. Selanjutnya, untuk peserta didik yang kemampuan pemecahan masalahnya kurang baik, mampu menjelaskan dan melaksanakan rencana yang telah ditentukan namun dengan prosedur yang kurang tepat sehingga melakukan kesalahan dalam perhitungan, bahkan pada beberapa soal peserta didik tidak mampu menuliskan penyelesaian karena beranggapan bahwa soal yang diberikan cukup sulit.

Peserta didik yang berada pada tahap level 0 (Visualisasi), rata-rata memiliki kemampuan yang kurang baik dalam melihat kembali. Mereka mampu menuliskan kesimpulan namun masih banyak yang kurang tepat dan tidak mampu menuliskan pengecekan jawaban dari penyelesaian yang telah dilakukan. Berdasarkan pembahasan tersebut, dapat diketahui bahwa peserta didik kelompok level 0 (visualisasi) sudah mampu melakukan tahap memahami masalah dengan baik namun masih kurang sempurna dalam membuat rencana dan melaksanakan rencana penyelesaian.

\section{Kemampuan yang Diperoleh Kelompok Level 1 (Analisis)}

Mayoritas peserta didik kelas VIII MTs Negeri

1 Mataram yang berada pada level 1 (analisis) memiliki kemampuan pemecahan masalah yang baik. Peserta didik yang berada pada tahap level 1 (analisis), rata-rata memiliki kemampuan yang sangat baik dalam memahami masalah. Peserta didik yang kemampuan pemecahan masalahnya sangat baik, baik dan cukup baik sudah mampu menuliskan dan menjelaskan apa yang diketahui dan ditanyakan dari soal dengan benar dan lengkap serta mampu mengidentifiksi bahwa data yang diberikan cukup untuk menyelesaikan soal.

Peserta didik yang berada pada tahap level 1 (analisis), rata-rata memiliki kemampuan yang baik dalam membuat rencana. Peserta didik yang kemampuan pemecahan masalahnya sangat baik sudah mampu merencanakan penyelesaian masalah dengan menuliskan dan menjelaskan aturan mtematika (rumus) dengan benar dan lengkap. Selanjutnya, untuk peserta didik yang kemampuan pemecahan masalahnya baik dan cukup baik, diperoleh bahwa peserta didik tersebut sudah mampu merencanakan penyelesaian masalah dengan menuliskan dan menjelaskan aturan mtematika (rumus) dengan benar dan lengkap namun pada beberapa pekerjaannya peserta didik kurang tepat dalam menuliskan rumus yang digunakan untuk menyelesaikan soal tersebut.

Peserta didik yang berada pada tahap level 1(analisis), rata-rata memiliki kemampuan yang baik dalam melaksanakan rencana penyelesaian. Peserta didik yang kemampuan pemecahan masalahnya sangat baik dan baik sudah mampu menjelaskan dan melaksanakan rencana yang telah ditentukan dengan 
prosedur yang benar dan melakukan perhitungan yang benar pada setiap langkah pengerjaan. Selanjutnya, untuk peserta didik yang kemampuan pemecahan masalahnya cukup baik mampu menjelaskan dan melaksanakan rencana yang telah ditentukan dengan benar dan lengkap namun pada beberapa soal peserta didik menuliskan prosedur yang kurang lengkap sehingga melakukan kesalahan dalam perhitungan.

Peserta didik yang berada pada tahap level 1 (analisis), rata-rata memiliki kemampuan yang kurang baik dalam melihat kembali. Peserta didik yang kemampuan pemecahan masalahnya sangat baik sudah mampu menarik kesimpulan dengan tepat namun tidak dapat menuliskan pengecekan kembali jawaban karena peserta didik tidak mengetahui cara mengecek jawaban. Selanjutnya, untuk peserta didik yang memiliki kemampuan pemecahan masalah geometri yang baik dan cukup baik, diketahui bahwa mereka sudah mampu menuliskan kesimpulan namun masih kurang tepat dan tidak mampu menuliskan pengecekan jawaban dari penyelesaian yang telah dilakukan.

Berdasarkan pembahasan tersebut, peserta didik kelompok level 1 (analisis) sudah mampu melakukan tahap memahami masalah, membuat rencana dan melaksanakan rencana. Namun dalam tahap melihat kembali, peserta didik tidak mampu memeriksa kembali hasil penyelesaiannya dan tidak mampu meyakinkan diri bahwa hasil penyelesaiannya sudah dilakukan dengan benar.

\section{Kemampuan yang Diperoleh Kelompok Level 2 (Deduksi Informal)}

Mayoritas peserta didik kelas VIII MTs Negeri 1 Mataram yang berada pada level 2 (deduksi informal) memiliki kemampuan pemecahan masalah yang baik. Peserta didik yang berada pada tahap 2 (deduksi informal), rata-rata memiliki kemampuan yang sangat baik dalam memahami masalah. Peserta didik yang kemampuan pemecahan masalahnya sangat baik, dan baik sudah mampu menuliskan dan menjelaskan apa yang diketahui dan ditanyakan dari soal dengan benar dan lengkap serta mampu mengidentifiksi bahwa data yang diberikan cukup untuk menyelesaikan soal.

Peserta didik yang berada pada tahap level 2 (deduksi informal), rata-rata memiliki kemampuan yang sangat baik dalam membuat rencana. Peserta didik yang kemampuan pemecahan masalahnya sangat baik sudah mampu merencanakan penyelesaian masalah dengan menuliskan dan menjelaskan aturan mtematika (rumus) dengan benar dan lengkap. Selanjutnya, untuk peserta didik yang kemampuan pemecahan masalahnya baik, diperoleh bahwa peserta didik tersebut mampu mencari hubungan antara data yang diketahui dan ditanyakan pada soal dan mampu merencanakan penyelesaian masalah dengan menuliskan dan menjelaskan aturan mtematika (rumus) dengan benar dan lengkap namun ada juga peserta didik yang tidak menuliskan secara lengkap rumus yang digunakan pada beberapa soal dengan alasan teburu-buru dan merasa waktu yang diberikan untuk mengerjakan masih kurang.

Peserta didik yang berada pada tahap level 2 (deduksi informal), rata-rata memiliki kemampuan yang sangat baik dalam melaksanakan rencana penyelesaian. Peserta didik yang kemampuan pemecahan masalahnya sangat baik dan baik sudah mampu menjelaskan dan melaksanakan rencana yang telah ditentukan dengan prosedur yang tepat dan melakukan perhitungan yang benar pada setiap langkah pengerjaan.

Peserta didik yang berada pada tahap level 2 (deduksi informal), rata-rata memiliki kemampuan yang baik dalam melihat kembali. Peserta didik sudah mampu menarik kesimpulan dengan tepat namun hanya beberapa peserta didik yang dapat menuliskan pengecekan kembali jawaban meskipun belum tepat karena peserta didik tidak mengetahui cara mengecek jawaban dan hanya mencoba-coba melakukan perhitungan ulang untuk mengetahui kebenaran dari jawaban yang mereka hasilkan. Peserta didik pada level 2 (deduksi informal) mulai mampu untuk melakukan penarikan kesimpulan secara deduktif tetapi baru pada tahap awal, artinya belum berkembang baik. Berdasarkan pembahasan di atas, peserta didik kelompok level 2 (deduksi informal) sudah mampu melakukan tahap memahami masalah, membuat rencana, melaksanakan rencana penyelesaian dan melihat kembali meskipun belum sempurna pada tahap melihat kembali [12].

\section{Kemampuan yang Diperoleh Kelompok Level 3 (Deduksi)}

Berdasarkan hasil penelitian dari 4 peserta didik kelas VIII MTs Negeri 1 Mataram yang berada pada level 3 (deduksi), dapat diketahui bahwa seluruh peserta didik kelas VIII MTs Negeri 1 Mataram yang berada pada level 3 (deduksi) memiliki kemampuan pemecahan masalah yang sangat baik.Peserta didik yang berada pada tahap 3 (deduksi), rata-rata memiliki kemampuan yang sangat baik dalam memahami masalah. Peserta didik pada level 3, peserta didik sudah mampu menuliskan dan menjelaskan apa yang diketahui dan ditanyakan dari soal dengan benar dan lengkap serta mampu mengidentifiksi bahwa data yang diberikan cukup untuk menyelesaikan soal.

Peserta didik yang berada pada tahap level 3 (deduksi), rata-rata memiliki kemampuan yang sangat baik dalam membuat rencana dan melaksanakan rencana penyelesaian. Peserta didik sudah mampu mencari hubungan antara data yang diketahui dan ditanyakan pada soal dengan sangat baik sehingga mereka dapat merencanakan penyelesaian masalah dengan menuliskan dan menjelaskan aturan mtematika (rumus) dengan benar dan lengkap. Peserta didik sudah mampu menjelaskan dan melaksanakan rencana yang telah ditentukan dengan prosedur yang 
tepat dan melakukan perhitungan yang benar pada setiap langkah pengerjaan.

Peserta didik yang berada pada tahap level 3 (deduksi), rata-rata memiliki kemampuan yang sangat baik dalam melihat kembali. Peserta didik sudah mampu menarik kesimpulan dengan dan menuliskan pengecekan kembali jawaban dengan tepat untuk mengetahui kebenaran dari jawaban yang mereka hasilkan. Berdasarkan pembahasan tersebut, maka dapat diketahui bahwa peserta didik kelompok level 3 (deduksi) sudah mampu melakukan tahap memahami masalah, membuat rencana, melaksanakan rencana dan melihat kembali dengan tepat dan proses perhitungan yang dilakukan juga dilakukan dengan tepat.

\section{Kemampuan yang Diperoleh Kelompok Level 4 (Rigor/Ketepatan)}

Berdasarkan hasil penelitian, kemampuan pemecahan masalah peserta didik pada level 4 (rigor/ketepatan) tidak dapat diungkapkan, hal tersebut karena tidak ada peserta didik kelas VIII MTs Negeri 1 Mataram yang mencapai level ini. Peserta didik pada level 4 (rigor/ketepatan) sudah memahami betapa pentingnya ketepatan dari prinsip-prinsip dasar yang melandasi suatu pembuktian karena merupakan level tertinggi dalam memahami geometri sehingga pada tahap ini memerlukan tahap berpikir yang kompleks dan rumit [12].

\section{TEMUAN LAIN}

Setelah proses pengumpulan data dan analisis data ternyata didapat temuan bahwa terdapat peserta didik yang belum mampu mencapai level 0 (visualisasi), sehingga dikelompokkan ke dalam level Pre 0 (Previsualisasi). Berdasarkan hasil penelitian dari 8 peserta didik kelas VIII MTs Negeri 1 Mataram yang berada pada level Pre 0 (previsualisasi), dapat diketahui bahwa seluruh peserta didik kelas VIII MTs Negeri 1 Mataram yang berada pada level pre 0 (pevisualisasi) memiliki kemampuan pemecahan masalah yang kurang baik. Peserta didik yang berada pada level pre 0 (pevisualisasi), rata-rata memiliki kemampuan yang cukup baik dalam memahami masalah. Peserta didik sudah mampu menjelaskan apa yang diketahui dan apa yang ditanyakan dari soal dengan benar untuk beberapa soal saja walaupun pada pekerjaannya ia tidak lengkap menuliskan apa yang diketahui dan apa yang ditanyakan. Peserta didik pada tahap ini mengalami kesulitan untuk mengidentifikasi bahwa data yang diberikan cukup untuk menyelesaikan soal.

Peserta didik yang berada pada level pre 0 (pevisualisasi), rata-rata memiliki kemampuan yang kurang baik dalam membuat rencana dan melaksanakan rencana penyelesaian. Peserta didik pada level ini tidak mampu mencari hubungan antara data yang diketahui dan ditanyakan dari soal karena keterbatasan kemampuan mereka dalam memahami soal sehingga peserta didik pada tahap ini kesulitan dalam memilih rumus apa yang digunakan dalam menyelesaikan permasalahan yang diberikan.

Peserta didik yang berada pada tahap level pre 0 (pevisualisasi), rata-rata memiliki kemampuan yang sangat kurang baik dalam melihat kembali mereka didik tidak mampu menuliskan kesimpulan dan pengecekan jawaban dari penyelesaian yang telah dilakukan. Berdasarkan pembahasan tersebut, peserta didik kelompok level pre 0 (pevisualisasi) hanya mampu melakukan tahap memahami masalah meskipun belum sempurna. Adapun untuk tahap membuat rencana, melaksanakan rencana dan melihat kembali, peserta didik pada level ini tidak dapat melakukannya dengan tepat.

Adapun dari hasil penelitian, dapat diketahui faktor penyebab peserta didik tidak mampu mencapai level berpikir yang lebih tinggi adalah:

a. Level 0 (Visualisasi)

Fakta bahwa sebagian besar ketidakmampuan peserta didik mencapai tahap berpikir visualisasi disebabkan oleh factor; (1) peserta didik salah dalam menentukan konsep-konsep geometri, (2) peserta didik salah dalam menentukan nama dalam suatu bangun geometri berdasarkan sifat yang diketahui

b. Level 1 (Analisis)

Fakta bahwa sebagian besar ketidakmampuan peserta didik mencapai tahap berpikir analisisi disebabkan oleh factor; (1)peserta didik megalami kekurangan kosakata dalam mengungkapkan ide-idenya yang ia miliki untuk menyelesaikan soal yang diberikan, (2) peserta didik melakukan kesalahan dala melakukan penghitungan dan penentuan suatu konsep, (3) peserta didik tidak mampu membuat simpulan dari proses penrhitungan dan penyelesaian soal yang telah dilaksanakan

c. Level 2 (Deduksi Informal)

Fakta bahwa sebagian besar ketidakmampuan peserta didik mencapai tahap berpikir deduksi informal disebabkan oleh faktor: (1) peserta didik mengalami kesulitan dalam melakukan perhitungan, (2) peserta didik tidak mampu membuat simpulan dari proses penrhitungan dan penyelidikan yang telah dilaksanakan

d. Level 3 (Deduksi)

Fakta bahwa sebagian besar ketidakmampuan peserta didik mencapai tahap berpikir deduksi disebabkan oleh faktor: (1) peserta didik kurang teliti dalam melakukan perhitungan, (2)peserta didik mengalami kesulitan dalam menyelidiki kebenaran hasil penyelesaian yang diperoleh

e. Level 4 (Rigor/Ketepatan)

Fakta bahwa sebagian besar ketidakmampuan peserta didik mencapai tahap berpikir rigor/ketepatani disebabkan oleh faktor ketidakmampuan peserta didik dalam memahami betapa pentingnya ketepatan dari prinsip-prinsip dasar yang melandasi suatu pembuktian. 


\section{KESIMPULAN}

Berdasarkan hasil penelitian dan pembahasan yang telah dipaparkan maka dapat diambil kesimpulan bahwa tingkat berpikir peserta didik kelas VIII MTs Negeri 1 Mataram secara umum dominan berada pada level 0 (Visualisasi). Adapun persentase banyaknya peserta didik pada masing-masing level berpikir Van Hiele yaitu; $8,25 \%$ peserta didik berada pada Pre 0 (previsualisasi), 48,45\% peserta didik berada pada level 0 (visualisasi), 30,93\% peserta didik berada pada level 1 (analisis), 8,25\% peserta didik berada pada level 2 (deduksi informal), $4,12 \%$ peserta didik berada pada level 3 (deduksi), dan 0\% peserta didik berada pada level 4 (rigor/ketepaan). Dalam pemecahan masalah geometri sesuai tahapan Polya, peserta didik yang berada pada kelompok level 0 (visualisasi) sudah mampu melakukan tahap memahami masalah dengan baik namun masih kurang sempurna dalam membuat rencana dan melaksanakan rencana penyelesaian. Peserta didik kelompok level 1 (analisis) sudah mampu melakukan tahap memahami masalah, membuat rencana dan melaksanakan rencana, namun dalam tahap melihat kembali, peserta didik tidak mampu memeriksa kembali hasil penyelesaiannya. Peserta didik kelompok level 2 (deduksi informal) sudah mampu melakukan tahap memahami masalah, membuat rencana, melaksanakan rencana penyelesaian dan melihat kembali meskipun belum sempurna pada tahap melihat kembali. Peserta didik kelompok level 3 (deduksi) memiliki kemampuan pemecahan masalah yang sangat baik, mereka sudah mampu melakukan tahap memahami masalah, membuat rencana, melaksanakan rencana dan melihat kembali dengan tepat dan proses perhitungan juga dilakukan dengan tepat. Hal tersebut menunjukan bahwa semakin tinggi tingkat berpikir Van Hiele peserta didik, maka kemampuan pemecahan masalah geometri yang dimilikinya akan semakin baik.

\section{DAFTAR PUSTAKA}

[1] Turmuzi, Muhammad. 2016. Geometri Bidang Datar. Mataram: FKIP Universitas Mataram.

[2] Khoiriyah, Nor. 2013. Analisis Tingkat Berpikir Peserta didik Berdasarkan Teori Van Hiele Pada
Materi Dimensi Tiga Ditinjau dari Gaya Kognitif Field Dependent dan Field Independent. Jurnal Pendidikan Matematika:1-1

[3] Abdussakir. 2010. Pembelajaran Geometri Sesuai Teori Van Hiele. Jurnal Kependidikan dan Keagamaan, 7, (2), 1-12.

[4] National Council of Teacher of Mathematics (NCTM). 2000. Principles and Standars for School Mathematics. Reston, VA: NCTM.

[5] Hudino. 2005. Meningkatkan Kemampuan Refresentasi dan Pemecahan Masalah Peserta didik SMA Melalui Model Pembelajaran Mathematics Project. Skripsi. FPMIPA UPI Bandung: Tidak diterbitkan

[6] Polya, G. 1973. How to Solve it. New Jersey: Princeton University Press.

[7] Chairani, Z. 2016. Metakognisi Siswa dalam Pemecahan Masalah Matematika. Yogyakarta: Depublish.

[8] Mullis, I., Martin, M.O. \& Foy, P. 2011. TIMSS 2011 International Results in Mathematics. Chesnut Hills: Boston College.

[9] Dunbar, K. \& Fugelsang, J. 2006. An Introduction to Cognitive Psychology.Toronto: Department of Phsycologi, Toronto University.

[10] Dyah, Tyas Setiana. 2017. Analisis Kemampuan Berpikir Geometri Van Hiele Peserta didik SMA Negeri Wangon ditinjau dari Adversity Quotient (AQ). Skripsi. Program Studi Pendidikan Matematika: Muhammadiyah Purwokerto.

[11] Van de Walle, John A. 1994. Elementary school mathematics: teaching developmentally. New York: Longman.

[12] Sutarto \& Syarifudin. 2013. Desain Pembelajaran Matematika. Yogyakarta: Samudra Biru.

[13] Herlambang. 2013. Analisis kemampuan Pemecahan Masalah matematika Peserta didik kelas VII-A SMP Negeri 1 Kepahiang tentang Bangun datar Ditinjau dari Teori van Hiele. Tesis. Program Studi Pascasarjana Pendidikan Matematika FKIP Universitas Bengkulu. 